\title{
THE PREVALENCE OF LOW ANTERIOR RESECTION SYNDROME IN RECTAL CANCER PATIENTS WHO UNDERWENT SURGICAL TREATMENT IN ISFAHAN CITY HOSPITAL DURING 2012-2018
}

Behnam Sanei, Mohammad Ghasemi Fard, Mohsen Kolahduzan

Department of Surgery, Alzahra Educational Medical Hospital, Isfahan University of Medical Sciences, Isfahan, Iran

\section{PREVALENCIJA SINDROMA NISKE PREDNJE RESEKCIJE KOD BOLESNIKA SA KARCINOMOM REKTUMA KOJI SU BILI PODVRGNUTI HIRURŠKOM LEČENJU U GRADSKOJ BOLNICI ISFAHAN TOKOM 2012-2018.}

\author{
Benam Sanei, Muhamed Gasemi Fard, Mohsen Kolahdozan \\ Odeljenje za hirurgiju, Obrazovna medicinska bolnica Alzahra, Univerzitet medicinskih nauka Isfahan, Isfahan, Iran
}

\begin{abstract}
Objective. We aimed to determine the relative frequency of low anterior resection syndrome (LARS) in patients with rectal cancers who underwent surgical treatment in Isfahan.

Methods. We evaluated all patients who were referred to the surgery clinic of Saint Al-Zahra hospital in Isfahan within six years. If LARS was identified, according to the LARS score tool, the frequency of resection complications, factors affecting the LARS, morbidity, and mortality, the frequency distribution of defecation, stool consistency, and rate of significant improvement was evaluated.

Results. Fifty-two patients were evaluated. The prevalence of LARS was 78.8\%. Postoperative fecal and gas incontinence, clustering, fecal frequency, and fecal urgency in LARS patients were significantly higher than in patients without LARS $(P<0.05)$. There was no significant difference between the two groups in terms of factors affecting the LARS $(p<0.05)$. In most of the patients with LARS, the defecation frequency was more than seven times a week (82.1\%), and they mostly had liquid stool (61.5\%). 95.5\% of the patients with LARS showed significant improvement, which was mostly after 7-11 months (38.5). There was a significant difference between the frequency distribution of defecation, stool consistency, and significant improvement status in patients with and without LARS.
\end{abstract}

Conclusion. LARS occurs commonly among patients undergoing LAR with TME and it is associated with more resection complications. Patients with LARS have significantly higher frequency of defecation per week and liquid stools and mostly achieve significant improvements. Other factors might not be significantly different between patients with or without LARS

Key words: colorectal surgery; rectal neoplasms; postoperative complications; fecal incontinence; short bowel syndrome.

\section{INTRODUCTION}

Rectal cancer is one of the most common fatal neoplasms and the second most prevalent cancer of the colon, which develops in the inner parts of the rectum or colon $(1,2)$. Based on the site of tumor origin, colorectal cancer has different clinical manifestations (3). Tumors of the proximal part of the colon mostly demonstrate

\section{SAŽETAK}

Cilj. Cilj nam je bio da utvrdimo relativnu učestalost sindroma niske prednje resekcije (LARS) kod pacijenata sa karcinomom rektuma koji su bili podvrgnuti hirurškom lečenju u Isfahanu.

Metode. Evaluirali smo sve pacijente koji su se u roku od šest godina obratili hirurškoj klinici bolnice Saint Al-Zahra u Isfahanu. Nakon identifikacije LARS, prema alatu za ocenu LARS, izvršena je procena učestalosti komplikacija resekcije, faktora koji utiču na LARS, morbiditeta i mortaliteta, učestalosti distribucije defekacije, konzistencija stolice $i$ stope značajnog poboljšanja.

Rezultati. Izvršili smo evaluaciju 52 pacijenta. Prevalencija LARS bila je 78,8\%. Postoperativna fekalna $i$ gasna inkontinencija, grupisanje, učestalost fekalija i fekalna hitnost kod pacijenata sa LARS bili su znatno veci nego kod pacijenata bez LARS $(p<0,05)$. Nije bilo značajne razlike između dve grupe u pogledu faktora koji utiču na LARS $(p<0,05)$. Kod vecine pacijenata sa LARS učestalost defekacije bila je više od sedam puta nedeljno (82,1\%), a uglavnom su imali tečnu stolicu (61,5\%). Kod 95,5\% pacijenata sa LARS pokazalo se značajno poboljšanje, koje je bilo uglavnom posle 7-11 meseci (38,5). Postojala je značajna razlika između učestalosti distribucije defekacije, konzistencije stolice $i$ značajnog poboljšanja statusa kod pacijenata sa LARS i bez njega.

Zaključak. LARS se često javlja kod pacijenata koji su podvrgnuti LAR sa TME i povezan je sa vecim komplikacijama resekcije. Pacijenti sa LARS imaju znatno veću učestalost defekacije nedeljno i tečne stolice i uglavnom postižu značajna poboljšanja. Ostali faktori verovatno nisu značajno različiti između pacijenata sa LARS ili bez njega.

Ključne reči: kolorektalna hirurgija; rektalne neoplazme; postoperativne komplikacije; fekalna inkontinencija; sindrom kratkog creva.

systemic symptoms, such as microcytic anemia and weight loss (4). On the other hand, distal colon tumors are found to manifest local symptoms such as changes in the intestinal habits and rectal bleeding (5). Approximately $95 \%$ of the colorectal cancers are reported to be of the adenocarcinoma type, and the other types of colorectal tumors include carcinoid tumor, stromal mass, lymphoma, 
and sarcoma (2). Reports from multiple studies suggest that the chance of developing rectal cancer in different regions differ (3). In a study in the United States, the probability of developing rectal cancer in men was about $5 \%$ (1 per 21$)$ and in women was about $4 \%$ (1 per 23$)$ (6). The prevalence of colorectal cancer in Iran has been reported between 8.1 and 8.3 per 100 thousand individuals (7). Both environmental and genetic factors correlate with the incidence of colorectal cancers. The most critical risk factor for this disease is positive family history. Other remarkable risk factors include a low level of physical activity, increased alcohol consumption, tobacco smoking, and high body mass index (BMI) $(8,9)$.

Diagnosis of the colorectal cancers is mainly based on colonoscopy findings (10). Other diagnostic methods include physical examination, biopsy, and serology tests (11). Complete surgical resection is considered as the primary treatment for the localized rectal cancers, although the type of cancer and patients' conditions would have a significant impact on the consideration of chemotherapy (12). One of the possible critical complications of colorectal surgery is the development of low anterior resection syndrome (LARS), which might occur in up to 80 percent of patients (13). Clinically, LARS is defined as disordered bowel function following rectal resection with subsequent impairment in quality of life, as described previously (14) . However, despite numerous investigations on the symptoms which a LARSaffected patient might demonstrate, a consensus specific definition of LARS has not yet been established (13). LARS might be manifested with different symptoms including gas and stool incontinence, urgency, increase in the intestinal movements and clustering of stools, and has a variety of different pathophysiological pathways, including the functional complications of the internal anal sphincter and reduced sensitivity of the anal canal (14, 15). Various studies have investigated the rate of postsurgical LARS incidence in patients with colorectal cancers (14). Accordingly, in this study, we aimed to determine the relative frequency of LARS in patients with rectal cancers who underwent rectal surgery as the treatment.

\section{PATIENTS AND METHODS}

This cross-sectional study evaluated patients with a definitive diagnosis of rectal cancers who were candidates for resection surgery and had been referred to the surgery clinic of Saint Al-Zahra hospital in Isfahan city from 2012 to 2018. Using the census sampling method, we acquired a list of all patients who were referred to the clinic within six years. Inclusion criteria were the age of 18 years and above, definite diagnosis of rectal rectum based on the pathology results, being a candidate for tumor resection surgery using Low anterior resection (LAR) with total mesorectal excision (TME) method and also informed written consent for participation in the study. The exclusion criteria were the failure of patient follow-up, lack of written consent, and the unwillingness of patients to continue cooperation in the study. After each patient underwent his/her surgical operation, we explained the study aim and methods to them and obtained written informed consent from them.

We determined the presence or absence of LARS according to the LARS score, a simple, applicable instrument for evaluating the bowel function after rectal cancer resection, which has a considerable sensitivity and specificity (16). After dividing patients into LARS and non-LARS groups, we acquired the frequency of resection complications (such as postoperative fecal incontinence, postoperative gas incontinence, clustering, fecal frequency, and fecal urgency) using a questionnaire. Also, factors affecting the LARS (including age, gender, the presence of ostomy, pre and postoperative chemoradiotherapy, anastomose type and site, concurrent pelvic surgery, duration of the surgical operation, distance of the tumor from the anal verge, distance of the anastomosis from the anal verge), morbidity and mortality were documented in a questionnaire by reviewing the patients' medical records. The frequency distribution of defecation (between 1 to 3 times per day, between 3 to 7 times per day and more than seven times per day) and stool consistency (Hard lumps, Sausage-shaped, Fingershaped, Soft blobs, Fluffy pieces, Liquid-according to Bristol stool chart) were also evaluated and recorded using a questionnaire. Finally, after a 24 months follow-up of patients, their morbidity and mortality status and the rate of significant improvement by month was evaluated.

Information was analyzed using SPSS software (IBM Corp. Released 2013. IBM SPSS Statistics for Windows, Version 24.0. Armonk, NY: IBM Corp.). Quantitative data were expressed as mean and standard deviation, and qualitative data were demonstrated as number and percentage. The qualitative data were compared using Chi-square and Fisher's exact tests, and the T-Test was used to compare quantitative data. The significance level of statistical tests was defined as $\mathrm{P}$-value $>0.05$.

\section{RESULTS}

In this study, we evaluated the data of 52 patients with rectal cancers. There was a total of $65.4 \%$ males and $34.6 \%$ females with the mean age of $58.69 \pm 10.20$ years, ranging from 30 to 75 . The $78.8 \%$ of patients had LARS. Resection complications in both patients with or without LARS are demonstrated in Table 1. Postoperative fecal incontinence, postoperative gas incontinence, clustering, fecal frequency, and fecal urgency in LARS patients were significantly higher than in patients without LARS $(\mathrm{P}<0.05)$ (Table 1). 
Table 1. Comparison of the frequency of resection complications in patients with or without LARS.

\begin{tabular}{|l|c|c|c|c|}
\hline Variable & Category & With LARS & Without LARS & P-value \\
\hline Postoperative fecal incontinence & Yes & $16(41 \%)$ & $0(0 \%)$ & $0.01^{*}$ \\
& No & $23(59 \%)$ & $11(100)$ & \\
\hline Post-operative gas incontinence & Yes & $36(59 \%)$ & $2(18.2 \%)$ & $<0.001^{*}$ \\
& No & $3(92.3 \%)$ & $9(81.8 \%)$ & \\
\hline Clustering & Yes & $39(100)$ & $4(36.4 \%)$ & $<0.001^{*}$ \\
& No & $0(0 \%)$ & $7(63.6 \%)$ & \\
\hline Fecal frequency & Yes & $39(100)$ & $5(45.5 \%)$ & $<0.001^{* *}$ \\
& No & $0(0 \%)$ & $6(54.5 \%)$ & \\
\hline Fecal urgency & Yes & $30(76.9 \%)$ & $0(0 \%)$ & $<0.001^{*}$ \\
& No & $9(23.1 \%)$ & $11(100 \%)$ & \\
\hline
\end{tabular}

${ }^{*}$ Chi-square test; ${ }^{* *}$ Fisher's exact test

Table 2. Factors affecting LARS.

\begin{tabular}{|l|c|c|c|c|}
\hline Variable & Category & With LARS & $\begin{array}{l}\text { Without } \\
\text { LARS }\end{array}$ & P-value \\
\hline Gender & Male & $27(65.9 \%)$ & $7(63.6 \%)$ & $0.89^{*}$ \\
& Female & $14(34.1 \%)$ & $4(36.4 \%)$ & \\
\hline Ostomy & Yes & $26(63.4 \%)$ & $6(54.5 \%)$ & $0.59 *$ \\
& No & $15(36.6 \%)$ & $5(45.5 \%)$ & \\
\hline Pre-operative chemoradiotherapy & Yes & $39(95.1 \%)$ & $10(90.9 \%)$ & $0.51^{* *}$ \\
& No & $2(4.9 \%)$ & $1(9.1 \%)$ & \\
\hline Post-operative chemoradiotherapy & Yes & $33(82.5 \%)$ & $6(54.5 \%)$ & $0.10^{*}$ \\
& No & $7(17.5 \%)$ & $5(45.5 \%)$ & \\
\hline Type of anastomosis & End-to-end & $2(4.9 \%)$ & $1(9.1 \%)$ & $0.51^{*}$ \\
& Side-to- & $39(95.1 \%)$ & $10(90.9 \%)$ & \\
\hline Site of anastomosis & end & & & \\
\hline Concurrent pelvic surgery & Coloanal & $13(32.5 \%)$ & $1(9.1 \%)$ & $0.12^{*}$ \\
& Colorectal & $27(67.5 \%)$ & $10(90.9 \%)$ & \\
\hline Mortality & Yes & $3(7.5 \%)$ & $0(0 \%)$ & $0.47 * *$ \\
& No & $37(92.5 \%)$ & $11(100 \%)$ & \\
\hline Age & Yes & $2(4.9 \%)$ & $1(9.1 \%)$ & $0.51^{* *}$ \\
\hline Duration of the pelvic surgery & No & $39(95.1 \%)$ & $10(90.9 \%)$ & \\
\hline Distance of the tumor from the anal verge & Years & $58.14 \pm 10.62$ & $60.72 \pm 8.55$ & $0.46^{* * *}$ \\
\hline Distance of the anastomosis from the anal & Cinutes & $271.95 \pm 80.06$ & $239.09 \pm 80.80$ & $0.23^{* * *}$ \\
\hline verge & Cm & $10.12 \pm 5.02$ & $10.00 \pm 2.05$ & $0.90^{* * *}$ \\
\hline
\end{tabular}

*Chi-square test; **Fisher's exact test; $* * *$ T-test

The results demonstrated in Table 2 revealed that most patients in both groups were males. Most patients with ostomy had undergone pre- and post-surgical chemoradiotherapy. Table 3 demonstrates the comparison of two LARS patient groups who underwent pre and post chemoradiotherapy sessions and either had an ostomy or did not. The most prevalent anastomosis type and site in most of the patients were side-to-end and colorectal, respectively. $7.5 \%$ of the patients with LARS and $0 \%$ of patients without LARS had undergone concurrent pelvic surgery. The mortality rate was $5.1 \%$ ( two subjects) in the LARS group and $9.1 \%$ (one subject) in the group without LARS. The mean duration of the operation and the distance of the tumor from the anal verge was higher in the LARS group than that of the group without LARS, and the mean age of the patient and the distance of the 
anastomosis from the anal verge were higher in the LARS group in comparison with the patients without LARS. The results of statistical tests showed that there was no significant difference between the two groups in terms of factors affecting the LARS ( $<<0.05)$ (Table 2 and 3).
As seen in Table 4, in most of the patients with LARS, the defecation frequency was more than seven times a week $(82.1 \%)$, and the liquid stool was the most common subtype of stool consistency (61.5\%). 95.5\%. of the patients with LARS showed significant improvement,

Table 3. Comparison of frequency of postoperative fecal incontinence, post-operative gas incontinence, clustering, fecal frequency and fecal urgency between LARS groups with and without ostomy who underwent pre-and postoperative chemoradiotherapy.

\begin{tabular}{|c|c|c|c|c|c|c|}
\hline \multicolumn{2}{|c|}{ Variable } & $\begin{array}{l}\text { Postoperative fecal } \\
\text { incontinence }\end{array}$ & $\begin{array}{l}\text { Post-operative gas } \\
\text { incontinence }\end{array}$ & Clustering & $\begin{array}{c}\text { Fecal } \\
\text { frequency }\end{array}$ & $\begin{array}{l}\text { Fecal } \\
\text { urgency }\end{array}$ \\
\hline \multicolumn{7}{|c|}{ Pre and post-operative chemoradiotherapy and LARS with ostomy } \\
\hline \multirow{2}{*}{ Yes } & $\mathrm{N}$ & 12 & 19 & 21 & 21 & 18 \\
\hline & $\%$ & 57.1 & 90.5 & 100.0 & 100.0 & 85.7 \\
\hline \multirow{2}{*}{ No } & $\mathrm{N}$ & 9 & 2 & 0 & 0 & 3 \\
\hline & $\%$ & 42.9 & 9.5 & 0 & 0 & 14.3 \\
\hline \multicolumn{7}{|c|}{ Pre and post-operative chemoradiotherapy and LARS without ostomy } \\
\hline \multirow{2}{*}{ Yes } & $\mathrm{N}$ & 3 & 11 & 11 & 11 & 9 \\
\hline & $\%$ & 27.3 & 100 & 100.0 & 100.0 & 81.8 \\
\hline \multirow{2}{*}{ No } & $\mathrm{N}$ & 8 & 0 & 0 & 0 & 2 \\
\hline & $\%$ & 72.7 & 0 & 0 & 0 & 18.2 \\
\hline \multicolumn{2}{|c|}{ P value } & $0.1^{*}$ & $0.53 * *$ & n.a. & n.a. & $0.99 * *$ \\
\hline
\end{tabular}

items including 21 subjects are missing sample No. 22. *Chi-square test; **Fisher's exact test; n.a. - not applicable

Table 4. Comparison of frequency distribution of defecation, stool consistency and significant improvement in patients with or without LARS.

\begin{tabular}{|c|c|c|c|}
\hline Variable & With LARS & Without LARS & P-value \\
\hline \multicolumn{4}{|c|}{ Frequency of defecation $* *$} \\
\hline 1-3 times/week & $0(0 \%)$ & $0(0 \%)$ & \multirow[t]{3}{*}{$0.001 * *$} \\
\hline 4-7 times/week & $7(17.9 \%)$ & $7(70.0 \%)$ & \\
\hline$>7$ times/week & $32(82.1 \%)$ & $3(30.0 \%)$ & \\
\hline \multicolumn{4}{|c|}{ Stool consistency* } \\
\hline Hard lumps & $0(0 \%)$ & $0(0 \%)$ & \multirow[t]{6}{*}{$0.01 *$} \\
\hline Sausage-shaped & $4(10.3 \%)$ & $2(20 \%)$ & \\
\hline Finger-shaped & $1(2.6 \%)$ & $3(30 \%)$ & \\
\hline Soft blobs & $9(23.1 \%)$ & $2(20 \%)$ & \\
\hline Fluffy pieces & $1(2.6 \%)$ & $1(10 \%)$ & \\
\hline Liquid & $24(61.5 \%)$ & $2(20 \%)$ & \\
\hline \multicolumn{4}{|c|}{ Significant improvement* } \\
\hline No & $2(4.9 \%)$ & $1(10 \%)$ & \multirow[t]{2}{*}{$0.51^{*}$} \\
\hline Yes & $39(95.1 \%)$ & $10(90.9 \%)$ & \\
\hline $3-5$ months & $11(28.2 \%)$ & $9(90 \%)$ & \multirow[t]{5}{*}{$0.007 *$} \\
\hline 6 months & $10(25.6 \%)$ & $0(0 \%)$ & \\
\hline 7-11 months & $15(38.5 \%)$ & $1(10 \%)$ & \\
\hline 12 months & $3(7.7 \%)$ & $0(0 \%)$ & \\
\hline 13-24 months & $0(0 \%)$ & $0(0 \%)$ & \\
\hline
\end{tabular}

*Fisher's exact test; ${ }^{* *}$ Chi-square test 
which was mostly after 7-11 months (38.5\%). Patients without LARS mostly had the frequency of defecation between 4-7 times a day, and the Finger-shaped stool was the most common subtype of stool consistency (30\%). $90.9 \%$ of patients without LARS had significant improvements, mostly after 3-5 months (90\%). ChiSquare and exact fisher test results showed that there was a significant difference between the frequency distribution of defecation, stool consistency, and significant improvement status in patients with and without LARS (Table 4).

\section{DISCUSSION}

This study aimed to evaluate multiple factors related to LARS in a two-year follow-up of patients with rectal cancers who underwent LAR with TME. Up to the date, there has been a limited study in this regard, and no similar studies have been conducted in Iran. Therefore, the findings of this study might help to understand the relationships of LARS-related factors with each other more specifically. A comprehensive definition for LARS is remarkably demanding, as instruments for diagnosing and evaluating LARS in patients reveal various findings because of different aspects of view to the bowel dysfunction $(13,14,17)$. Two widely-used clinical instruments for evaluating of LARS are The Memorial Sloan-Kettering Cancer Center Bowel Function Instrument (MSKCC BFI) and LARS score (18). The main reason for choosing the LARS score as a tool for evaluating anorectal function in this study is that the LARS score is a quick instrument with less comprehensive aspects in comparison with the MSKCC BFI and, therefore, more clinically-applicable $(13,18)$.

According to the findings of our study, following LAR with TME, $78.8 \%$ of patients developed LARS. Therefore, the notable prevalence of LARS in patients undergoing LAR with TME indicates that encountering bowel dysfunction is one of the significant complications following this method of surgery. Various reports on the prevalence of LARS following TME have raised the importance of recognizing the role of this surgical procedure in the onset of LARS. According to the results of the study Ekkarat et al. on the determination of effective factors on the incidence of LARS after rectal tumor resection, the incidence of major LARS was evident in about $28 \%$ of patients (19). Incidence of intestinal dysfunction in about $46 \%$ of patients with rectal cancer who were treated using TME method were observed in the study of Chen et al. (20). Also, evaluating the factors associated with the incidence of LARS in the study of Jimenez-Gomez et al. revealed that about $19 \%$ of patients subjected to TME method developed minor LARS and about 56\% suffered from major LARS (21). The prevalence of LARS in our study was higher compared to other studies, and this difference might be subjected to the utilization of different LARS scoring instruments, study periods, sample sizes, study methods, and definition of LARS (13).

After the surgical operation, the fecal incontinence, gas incontinence, clustering, fecal frequency, and fecal urgency in LARS patients was more evident in our study. Also, the rate of defecation more than seven times per week was more evident in the subjects with LARS, while in most patients without LARS, the frequency of defecation was between 4 to 7 times a week. Besides, most LARS patients had liquid stools, while most of the patients without LARS had finger-shaped stools. These variables are commonly considered in many questionnaires for the evaluation of anorectal function. It is noteworthy that some instruments for evaluating the bowel function (such as Wexner score) might consider the impact of some factors (such as incontinence or clustering) more seriously compared to other factors as the symptoms of LARS. In these instruments, the impact of variables such as urgency and clustering might probably be underestimated, while these factors might encompass significant effects on the quality of life of patients with LARS $(20,22)$. The results of the study Emmertesen et al., which investigated the intestinal function and quality of life of LARS patients, showed significant effects of intestinal problems following LAR with TME on the quality of life of patients (16).

The results of this study demonstrated the importance of considering the impacts of incontinence for flatus, incontinence for liquid stools, frequency, clustering, and urgency with the quality of life of patients. Also, the above findings were the most crucial factors in differentiating various types of LARS, according to the LARS score (16, 23). The findings of our study, regarding the resection complications variables, confirm that the factors mentioned earlier should be evaluated with more caution, as they might be more significantly observable in possible LARS patients. On the other hand, the existence or absence of ostomy, pre- and post-surgical chemoradiotherapy and age were not significantly different between patients with or without LARS. Additionally, most patients with ostomy had undergone pre- and post-surgical chemoradiotherapy. A comparison of patients who didn't have ostomy with this group revealed no significant difference in terms of postoperative fecal incontinence, post-operative gas incontinence, clustering, fecal frequency, and fecal urgency, suggesting that the presence of ostomy didn't pose a significant difference between LARS patients.

However, in different studies, these factors have demonstrated a variable relationship with LARS. For example, the results of the study Jimenez-Gomez et al. showed that age, pre- and post-surgical radiotherapy, post- 
surgical chemotherapy, as well as a protective ileostomy, were significantly associated with the development of major LARS (21). Based on the findings of the study Ekkarat et al., post-surgical radiotherapy and anastomosis level were associated with major LARS (19). Our findings are not similar with these results, as mentioned earlier. Sturiale et al. demonstrated an increase in the risk of developing major LARS with undergoing surgery at the age of 70 (24). Our findings are not consistent with the research, as mentioned above, as age was not significantly different between the study groups.

These conflicts in the findings may be due to the difference in the sample size and the method of our study as well as evaluated variables with other studies. One might consider the presence of post-radiation colitis in rectal cancer patients who receive such complex multistage treatment approaches. It is noteworthy that our study subjects had developed no pre- or post-operative radiotherapy complications in association with colitis, including hematochezia, diarrhea, abdominal pain, gastrointestinal bleeding, nausea, or vomiting. Besides, the onset of LARS symptoms had been closely monitored and began shortly (at most approximately two days after the surgery) in patients. The most notable symptoms in these patients were associated with their defecations, and as the symptoms improved over time, the clinical suspicion of such complications faded. Reviewing the reports of the consultant internists (which was available in cases with more complicated symptoms) ensured that the symptoms of the study subjects were less likely to be clinically related to other complications rather than LARS. These facts represent remarkable aspects of our study.

A significant limitation of our research is the usage of a single-center sampling setting. The rather small number of sample size subsequently results in the complexity of generalization of the results to the whole community. This limitation resulted in combining both minor and major LARS groups considering the risk of underfitting. Also, in this study, the evaluation of the manometric anorectal profile and its relationship with LARS was not evaluated due to the incompatible medical records of the patients. Therefore, due to the notable prevalence of LARS and the complexity that is evident in its differentiation and classification, it seems that more extensive studies in the field of TME surgery and its effects on the incidence of LARS could reveal more specified information in this regard.

In conclusion, the incidence of LARS was $78.8 \%$. LAR with TME was associated with more postoperative fecal and gas incontinence, clustering, fecal frequency, and urgency in comparison. Patients with LARS have a significantly higher frequency of defecation per week and liquid stools, and in comparison with the patients without LARS, they achieve significant improvements later. Other factors might not be significantly different between patients with or without LARS.

\section{ACKNOWLEDGMENT}

This study is based on a thesis of the general surgery residency course at Isfahan University of Medical Sciences. The Ethic Committee of Isfahan University of Medical Science approved this study with code IR.MUI.MED.REC.1397.049. We want to thank all the personnel of the Vice-Chancellor for Research in Isfahan Medical School and the hardworking staff of Saint-Al Zahra hospital of Isfahan city who helped us conduct this research.

\section{CONFLICT OF INTEREST}

The authors declare that there is no conflict of interest regarding the publication of this manuscript.

\section{FUNDING}

This Vice-Chancellor for Research of the School of Medicine in Isfahan has approved and supported this study.

\section{REFERENCES}

1. Fazeli M S, Keramati M R. Rectal cancer: a review. Med J Islam Repub Iran. 2015; 29 (1) :83-104.

2. Marley AR, Nan H. Epidemiology of colorectal cancer. Int. J. Mol. Epidemiology Genet. 2016; 7: 105-14.

3. Yang J, Du XL, Li ST, et al. Characteristics of differently located colorectal cancers support proximal and distal classification: a population-based study of 57,847 patients. PLoS One 2016; 11: e0167540-e. (doi: 10.1371/journal.pone.0167540).

4. Keeler BD, Mishra A, Stavrou CL, Beeby S, Simpson JA, Acheson AG. A cohort investigation of anaemia, treatment and the use of allogeneic blood transfusion in colorectal cancer surgery. Ann Med Surg (Lond) 2015; 6: 6-11.

5. Plummer JM, Leake P-A, Ferron-Boothe D, Roberts PO, Mitchell DI, McFarlane ME. Colorectal cancer survival in Jamaica. Ann Med Surg (Lond) 2016; 6: 26-9.

6. Ansa BE, Coughlin SS, Alema-Mensah E, Smith SA. Evaluation of colorectal cancer incidence trends in the United States (2000-2014). J Clin Med 2018; 7: 22. (doi: 10.3390/jcm7020022).

7. Rafiemanesh H, Pakzad R, Abedi M, et al. Colorectal cancer in Iran: Epidemiology and morphology trends. EXCLI J 2016; 15: 738-44. 
8. Wei EK, Giovannucci E, Wu K, Rosner B, Fuchs CS, Willett WC, et al. Comparison of risk factors for colon and rectal cancer. Int J Cancer 2004; 108: 433-42.

9. Johnson CM, Wei C, Ensor JE, et al. Meta-analyses of colorectal cancer risk factors. Cancer Causes Control 2013; 24: 1207-22.

10. Vega P, Valentín F, Cubiella J. Colorectal cancer diagnosis: pitfalls and opportunities. World J Gastrointest Oncol 2015; 7: 422-33.

11. Swiderska M, Choromańska B, Dąbrowska E, et al. The diagnostics of colorectal cancer. Contemp Oncol (Pozn) 2014; 18: 1-6.

12. Zhang Y, Chen Z, Li J. The current status of treatment for colorectal cancer in China: a systematic review. Medicine 2017; 96: e8242. (doi: 10.1097/MD.0000000000008242).

13. Keane C, Wells C, O'Grady G, Bissett IP. Defining low anterior resection syndrome: a systematic review of the literature. Colorectal Dis 2017; 19: 713-22.

14. Bryant CL, Lunniss PJ, Knowles CH, Thaha MA, Chan CL. Anterior resection syndrome. Lancet Oncol 2012;13: e403-8. (doi: 10.1016/S14702045(12)70236-X).

15. Ridolfi TJ, Berger N, Ludwig KA. Low anterior resection syndrome: current management and future directions. Clin Colon Rectal Surg 2016; 29: 239-45.

16. Emmertsen KJ, Laurberg S. Low anterior resection syndrome score: development and validation of a symptom-based scoring system for bowel dysfunction after low anterior resection for rectal cancer. Ann Surg 2012; 255: 922-8.
17. Martellucci J. Low anterior resection syndrome: a treatment algorithm. Dis Colon Rectum 2016; 59: 7982.

18. Chen TY-T, Emmertsen KJ, Laurberg S. What Are the best questionnaires to capture anorectal function after surgery in rectal cancer? Curr Colorectal Cancer Rep 2015; 11: 37-43.

19. Ekkarat P, Boonpipattanapong T, Tantiphlachiva K, Sangkhathat S. Factors determining low anterior resection syndrome after rectal cancer resection: a study in Thai patients. Asian J Surg 2016; 39: 225-31.

20. Chen TY, Wiltink LM, Nout RA, et al. Bowel function 14 years after preoperative short-course radiotherapy and total mesorectal excision for rectal cancer: report of a multicenter randomized trial. Clin Colorectal Cancer 2015; 14: 106-14.

21. Jimenez-Gomez LM, Espin-Basany E, et al. Factors associated with low anterior resection syndrome after surgical treatment of rectal cancer. Colorectal Dis 2018; 20: 195-200.

22. Chen TY, Emmertsen KJ, Laurberg S. Bowel dysfunction after rectal cancer treatment: a study comparing the specialist's versus patient's perspective. BMJ Open 2014; 4: e003374. (doi: 10.1136/bmjopen2013-003374).

23. Bjoern MX, Nielsen S, Perdawood SK. Quality of life after surgery for rectal cancer: a comparison of functional outcomes after transanal and laparoscopic approaches. J Gastrointest Surg 2019; 23: 1623-30.

24. Sturiale A, Martellucci J, Zurli L, et al. Long-term functional follow-up after anterior rectal resection for cancer. Int J Colorectal Dis 2017; 32: 83-8. 